\title{
第11 章＼cjkstart学会活動，照明教育，普及活動その他
}

\author{
（主查 広瀬 吉夫）
}

\section{1 学 会 活 動}

\subsection{1研究・調査に関する事項}

\section{I 。研究部門}

(1) 研究専門部会

(1) 光の発生・関連システム研究専門部会

(a) 本研究専門部会取扱い分野および年間，長期活動について 検討した.

(b) 公開研究会の企画・運営に当たった.

(c) '85 IES 大会の概況, および光源関連論文の調査を行なっ た。

（d）他学会および他研究専門部会との共催を実施した（公開研 究会および国際シンポジウム).

(e) 東京支部大会のシンポジウム参加を企画した.

(f) 公開研究会メンパーは92名となり, 公開研究会を 4 回開催 した（発表件数 8 件).

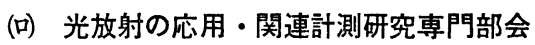

(a) 関連委員会・研究会および関連学協会との連携をとり, 研 究会の共催について，また開催方法・内容について検討した。

(b) 委員会の長期的方針について検討した.

(c) '85 国際シンポジウム拈よび電気・情報関連学会連合大会 シンポジウム, 東京支部大会シンポジウムの開催計画または内容 などについて検討した。

（d）光放射の測定に関する出版物の計画と内容について検討し た.

(e) 公開研究会メンパーは95名となり, 公開研究会は 3 回開催 した（発表件数 8 件).

(f) '85国際シンポジウム技術詩諭会の実施推進母体となり，討 論会を実施した。

(价視覚研究専門部会

(a) 現在視覚関係の委員会は二つあるが，それぞれきわめて活 発に活動しているため, 現在のところ特に問題なく, 部会委員会 を開催しなかった.

（b）視覚情報と視環境研究調查委員会に協力して，昭和61年度 全国大会にシンポジウムを提案した.

\section{$\Leftrightarrow$ 光環境研究専門部会}

(a) 公開研究会の企画, 運営に当たった。

（b）昭和61年度に必要な調査研究課題について審議し, 光環境 の設計技術の研究調查委員会の設置を提案した.

(c) '86 国際シンポジウムの講演内容, 講師について審議し, Rikard Küller 氏（スウェーデン, ルンド工科大学）を推萀し た.

（d）本委員会の規則(案)を作成し, 総務理事に提出した.

（e）会員制につき基本検討を進めた.

（f）東京支部大会のシンポジウム参加を企画した。

(g) 公開研究会を 4 件行なった (発表件数13件).
(2) 研究調查委員会

（1）電子点灯回路の実用化研究調查委員会

(a)これまでに収集した文献・資料をもとに，電子点灯回路の 荚用化の現状について検討を行ない，本委員会としてとり上げる べき調查・研究課題を討議した.

（b）広く委員諸氏と意見交換を行ならため，公開研究会を計画 した.

(c) 学会誌に点灯回路に関する解説記事を掲載することを検討 した.

（d）公開研究会を 1 回開催した（発表件数 7 件）.

(口) 演色性の評価方法研究調査委員会

(a) CIE TC-12 相対演色 1985 年 6 月, パリ会議用提案の最終 確認を行なった。

（b） パリ会議の CIE 演色性評価方法第 3 版案による 各種ラン プの評価数を調查, および試験色としての日本人肌色の新データ 調查を行なった.

(c) CIE で現在審議している演色性評価方法第 3 版の改良案を 審議・作成した.

(ソ) 輝度計の性能評価方法研究調查委員会

(a) 煇度計の性能項目（19項目）を設定し，それに対する評価 方法を定めた.

(b) 輝度計のしくみ, 輝度計使用上の注意事項を検討した.

(c) 輝度計による測定の実際例を調査検討した。

(d) 輝度計についての用語を検討設定した。

（e）報告書「輝度計の性能評価方法ならびに使用方法」を作成 し，委員会を解散した。

$\Leftrightarrow$ 視覚情報と視環境研究調查委員会

(a) 視覚系の時空間特性に関する報告と，CRT ディスプレィ のちらつきに関する報告について検討した.

(b) 応用物理学会の生理光学研究グループと共催で, 公開研究 会「視野々視機能」の開催について検討し, 公開研究会（発表件 数 7 件)を開催した.

(c) 研究報告書を提出して委員会を終了, 解散した.

(杖 光の量の視感覚による評価体系研究調査委員会

(a) 明所視, 薄明視, 暗所視の全視環境に有効な明るさの測光 システムの開発に向けての基礎研究を行なった.

（b）報告書を提出することによって研究会を終了, 解散した.

(ヘ)人間一機械系における照明環境研究調査委員会

(a) 心理・生野・産業衛生的側面から見たVDT 視作業の問題 点について討議した。

(b) エルゴノミクス面から見たVDT の現状と将来について討 議した。

(c) VDT 作業の照明所要条件を始め，ハードおよびソフト的 内容の両側面から VDT 問題に関して審議し, 一応, 初期の目標 を達成した. 
（d）報告書を提出することによって委員会を終了，解散した。

(卜) 高歯化社会における照明の研究調査委員会

(a) 高齢化社会の到来に対処するため, 年齢, 照度之近距離視 力との相互関係を調查し, 視作業に打ける年齢と必要照明条件の 関係を明確にすることを目的とする.

(b) 研究計画を策定し, 二つの分科会を設け具体的推進を図っ た.

(c) 高秢者を主体とした観测渚群より，文字指標を対象とした 近距離視力と, 色弁別機能に対する実験を中央鉄道病院で実 施 し，年踚と近距離視力および色弁別機能との関係を示寸基礎デー タが得られた。

（d）年踰と視覚機能に関する文献・資料を収集し検討した・な お。，高粭者に抢ける視作業および視環境における問題について検 討し，これに対する照明方式との関連について討議した.

(チ) 薄明視レベルの照明技術の研究調査委員会

(a) 作業推進のため 3 分科会を設けた.

(b) 薄明視の視感度関数について検討し, 実験用測光器（輝度 計，照度計）の準供方針を定めた。

（c）色票を対象として, 薄明視条件における見え方実験を実施 した.

(d) 各種光源別に，明所視と薄明視に抢けるランプ効辫の羕異 について計算によって検討を行なった。

（e）薄明視条件に対応する照明施設例の分類について検討し， 資料を収集した。

（f）次年度に括ける作業計画を決定した.

(リ) 光関連材料・デパイス研究調査委員会

(a) 光関連材料・デパイス研究専門部会設立の可能性について 委員対象にアンケートを実施して検討した結果, 会員確保につい て当面は困難が尒想されるが，時代的要請として必要であると答 申した。

（b）部会が取り上げる技術分野として, 光関連（紫外, 可視, 赤外）に関する材料・デバイス（情報通信は除く）とし, 照明関 連 (光源・器具・建材などの実務), 発光・放射・表示 (ディス プレイ,レーザなど), 受光・変換・伝送 (光センサ, 光ファイ バ，太陽電池など）とすることとした.

(又) セラミック材料研究調査委員会

（a）本委員の取扱い分野，および今後の活動方針について検討 した.

(b) 委員会に打けるヒアリングのテーマにつき審議し, 次の 10 項目を決定した. (1)電気光学セラミックス, (2)监光体材料, (3) ンプ用ガラス，(4)石英ガラス，(5)透光性セラミックス，(6)エミッ タ, (7)赤外反射膜, (8)ディスプレイ材料, (9)単結晶材料, (10)光フ ァイバ材料.

(c) 初年度は(1)〜 (8)までのヒアリングを行なった.

(l) ディスプレイ用材料・デバイス研究調查委員会

(a) 研究会テーマ, および調査内容と方法について方向付けを した.

(b) この分野の学会員外の権威者も委員にはいってもらい, テ レビジョン学会, SID 日本支部など他学会との連携がつくように なった.

(c) 公開研究会を 1 回 (発表件数 5 件), 非公開研究会を 1 回 開催した.

\section{(3) 特別研究委員会}

(1) 誘導灯の見え万に関する（そのII）特別研究委呈会

(a) 社団法人日本照明器具工業会の委託によるもので, 誘導灯 の見え方に影響を与学るノイズと誘導灯の見え方（判読性, 誘目 性）の関係を明らかにし，誘䍌灯の各種防火対象物への適用，お よび今後の器具開発の基礎資料を得ることを目的とする.

(b) 委員会において研究計画を策定し，2 分科会により具体的 推進を図った。

(c) 東京工業大学長津田キャンパスに拈いて，CRT ディスプ レイを利用した反応時間による誘目性の実験と, 写真によるノイ ズの定量的評価実験を行ない，それぞれ成果を得た。

(d) CRT ディスプレイを利用した実験は，当学会として新し い試みであるので，その内容を昭和 61 年 8 月の全国大会において 発表することとした.

(e) 報告書を委託元に提出し, 委員会を終了し, 解散した.

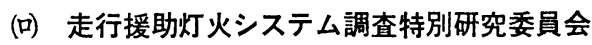

(a) 運輸省航空局管制保安部照明課からの委託で, 走行援助灯 システムを羽田沖展開等大替模空港に導入するために, 諸外国の 実地調查を含めた基礎的調查を行ない，このシステムの基本的性 能要件をとりまとめることを目的とする.

(b) 作業の効率的進行のため, WGを編成し，これにより資材 の収集, 調查, 報告書作成等の作業を進めた.

(c) 諸外国の実地調查には, 委員長を団長とする調查団を編成 し, 綿密な計画の基に, 英国ロンドンの 2 空港と西独フランクフ ルトの 1 空港に的を絞り, 前もって質問状を発送するなど連絡を 密にし, 有効から詳細な調查を行なった.

(d) 国内についても, 航空機の地上走行に対して行なっている 管制の状況を実地見学し，調査検討を行なった。

(e) パイロット側および設置側からの要求条件を総合的に検討 し, システムの基本的特性, 制御方法ならびにシステムの運用,

監視方法等についてとりまとめを行なった.

（f）報告書を委託元に提出し，委員会を終了，解散した。

II. 規格調査部門

(1) 照明関連 JIS の企画委員会

(a) 照明関連 JIS で，新規原案を作成すべき項目，改正すべき 項目について調查検討した。

（b）工業技術院からの要請により，今後の 5 年間の JIS 見直し 方針について，その計画案を作成し工業技術院に具申した。

(c) JIS Z 8113(照明用語)改正原案作成委員会を発足させた.

(d) 新時代の照明環境研究調査委員会報告の「新時代に適合す る照明環境の要件に関する調査研究」につき審議し, 技術指針と してふさわしいことを理事会に回答した.

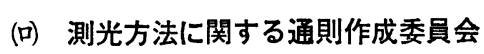

(a) 本委員会の効率的な運営方針について検討した。

(b) 原稿作成のための大まかなフォーマットを決定した.

(c) 執筆項目を定め執筆者および査読者を決定した.

(d) 執筆者から提出された原稿について, 查読者を中心に検討 を行なった。

（e）報告書の形式と出版の方法について検討した.

（f）本年度, 本委員会に提出された資料原稿件数は14件で, 約 40項目の予定内容のうち，13項目の原稿について審議が行なわ れた。

（g）委員会継続について審議し，申請することとした。 


\section{(v) 照明用語 JIS 改正原案作成委員会}

(a) 日本規格協会からの委託で，現行規格を全面的に見直し， 改託中の国際規格との整合を図り，現查に合致した内容に改訂す ることを目的とする.

(b) 視覚信号, 放射の応用の 2 分類を新設するほか, 色の用語 との整合のため, 従来の 6 分類から 7 分類へ改め 9 項目とした.

(c) 語数は現行の 250 語から, 全面通して280語を新たに採用し て合計約 500 語以上に拡張し，二つの分科会を編成し，これを調 整する調整小委員会を設け，原案を作成した.

（d） 報告書を委託元に提出し, 委員会を終了, 解散した.

\section{1 .2 業務, 事業に関するもの}

\section{I 。業 務 部 門}

(1) 編集委員会

学会誌編集に関する企画の立案, 審議, 各小委員会の活動状況 の把握, 学会誌関連経費の把握と検討, 英文誌委員会への関連事 項の伝達, 学会誌に関するアンケート調査の実施ならびに結果の 分析等を行なった.

\section{(a) 企画推進小委員会}

学会誌編集の企画推進, 特集号の企画立案, 学会誌に関するア ソッート調查の実施, 学会誌関連経費の検討.

\section{(b) 查境小委員会}

投稿原稿の查読「寄稿のしおり」, 「查読内規」の改正案作成.

\section{(c) 文献紹介小委員会}

国内および外国文献の調査紹介, 学会カレンダーの作成, 国内 および外国文献の略号の見直し.

\section{(d) ニュース・応用技術小委員会}

照明のデータ・シート, 施設報告, 学会誌表紙, 照明ニュース などの企画ならびに査読, 照明のデータ・シートのカラーページ を增やすことの検討.

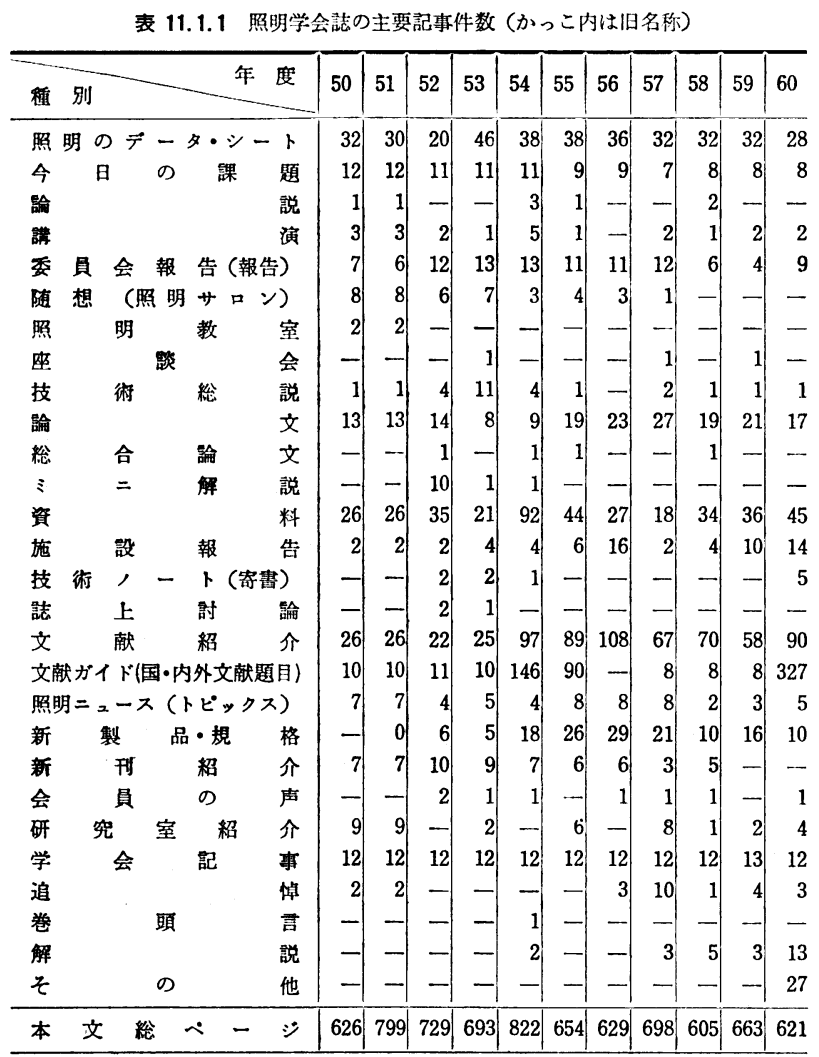

\section{(e) 学会誌の編集}

(1) 12 回発行 (69巻 4 号 70巻 3 号), 総ページ 1,042 頁, 月平均 87ページ (59年度は55ページ), (2)主要記事は 衰 11.1.1 参照, (3)特集号「科学万博一つくば’85の照明」(69巻 5 号),「バイオイ ンダストリーーに打ける光放射利用」(69巻11号),「北海道支部」 (70巻 3 号), (4)諭文号 69 巻 6 号, 10 号, 70 巻 2 号, (5)照明年報 69 巻 8 号.

(口) 照明発達調查委員会

(a) 昭和60年度照明年報の反省々本委員会の運営方針の審議.

（b）昭和61年度への申し送り事項検討, 年報の編成, 執筆者の 選定, 確認, 進行予定の審議.

(c) 㤠談会「小型変形蛍光ランプ」をテーマとして開催.

\section{(价英文誌委員会}

英文誌 Vol. 8 No. 1 ， 2 を発行. Vol. 8 No. 1 から専門会員 に配布した. 英文原稿作成の便宜をはかるため, 希望者に翻訳者 の翰旋を始めた. 従来の英文誌の abstract の字体の改善をVol. 10から実施することを検討した。

\section{$\Leftrightarrow \quad$ 第18回（昭和60年度）照明学会全国大会}

実行委員会の協力の下に，下記のとおり全国大会を開催した. 今年度は国祭科学技術博覧会 (つくば科学博) の開催に合わせ, 昨年度に引き続き東京で開催し, (1)特別講演「万博と照明」, (2) 科学万博バネル展示, (3)つくば科学万博見学会など, 万博関係の 企画を折り込み実施した.

(a) 開催日時 昭和 60 年 3 月 27,28 日（一般講演など)，3 月 29日, 30日 (見学会) 場所 東京理科大学神楽坂校舎.

(b) 参加者 439 名.

(c) 一般講演 111件, シンポジウム「VDT 作業と環境設計」 (10件), 特別講演 (前記), プログレスレポート「光源器具」(野 口透, 搑南大学), 「照明施設」(伊東 孝, 東京電機大学) .

(d) 第16回研究奖励賞授与式：受賞者 大野義弘君（松下電器 産業), 小野折郎君 (日立製作所), 内川恵二君 (東京工業大学:), 明道成君 (三蕧電機), 湯原恒平君（東芝電材）の 5 名.

(e) 僫視会 3 月27日同大学大会議室にて 110 名参加.

（朴）第19回（昭和61年度）照明学会全国大会委員会

全国大会基本事項の決定, 扎よびスケジュールの検討を行なっ た.

\section{（へ）昭和61年電気・情報関連学会連合大会対策委員会}

炤和61年掲題連合大会に, 当学会関係のシンポジウム課題とし て「遠赤外放射の基礎と新しい応用分野」「ディスプレイにおけ る色彩の諸問題」の 2 件を第 2 部会へ提出し， 2 件とも採択され た. 大会は昭和 61 年 9 月 $10 ， 11 ， 12$ 日の 3 日間, 中央大学で開催 予定.

\section{（ト）昭和61年度照明学会賞審査委員会}

下設 3 名（五十音順）を推萀した。

高橋貞雄君 (東芝電材秼研究所長), 桝見和孝 (神戸大学教育 学部教授 - 工博), 森田政明君 (松下電器産業(侏照明研究所電子 工業分室長)

\section{(千) 昭和61年度研究桨励賞赛査委員会}

下記 4 名（五十音順）を推鹰した. 川勝 晃君（秼東芝 光源 開発研究部), 田屋 明君 (秼東芝総合研究所), 富永守君 (秼) 東芝 総合研究所), 西村政信君 (大同工業大学電気工学科).

(リ) 事務機械化推進委員会

学会事務作業のうち, 機械化すべき事項, 特に会員情報データ 
ベースの内容と作成方法を審議し，それを処理するための機種を 調烃し, 審議の上選定した.

\section{(又) 学会誌編集, 印刷作業のあり方検討委員会}

照明学会誌編集作業分析, 同作栄の合理化, 近代化についての 協議, 同印刷工程の近代化方策の検討, 同外注先の調查.

II. 事 業 部 門

（价照明教育推進委員会

(a)「照明実務講座」第 5 期のスクーリングを全国 8 会場で開 催され，596名の「照明コンサルタント」（5か年間有効）が生ま れた（受講者783名, 認定証（優秀）153名, 認定証 443 名, 第 1 期からの累計4, 404名).

(b) 照明コンサルタント第 1 期生から第 5 期スクーリングに出 席を求め, 266 名に永久ライセンスの「照明コンサルタント認定 証」を交付した。

(c)「照明突務講座」第 6 期は 857 名が受講した. 第 1 期から の累計は 6,740 名.

(d)「照明専門講座」第 1 期を 7 月開講 (315 名受講)， 61 年 2 月スクーリングが開催され，279名の永久ライセンス「照明士」 が生まれた。

（e）次期, 照明「実務講座」「専門講座」の募集を行なった。

(p) 出版委員会

(a) 照明学会編：「安全で便利に使うための家庭の配線器具が イド」を 4 月に初版 67,000 部を発行.

(b) 照明学会編：「リフレッシュのための家庭の光源・照明器 具ガイト」を 9 月に初版 64,500 部発行.

(c) 照明学会編「大学課程・照明工学」第 1 版第 3 刷を 9 月に オーム社から1,500部発行. 累計 4,500 部.

(d) 大山松次郎著：「新編・照明講義案」第 2 版第 6 刷を 12 月 オーム社から500部発行. 累計8, 750部.

(e) 照明学会編：「住宅・店舗照明」(現代電気工事大系) 第 1 版 5 刷をオーム社から2,000部発行. 累計11,000部.

(f) 照明学会編：「照明適正化の諸問題」第 3 刷を，61年 2 月 に1,300部発行. 万ち900部を照明実務講座第 6 期スクーリング用 として，400 部は照明コンサルタント第 1 期拉よび次期認定更新 受講者に配布した。

(㚈国際シンポジウム委員会

(a) '85国際シンポジウムの開催

昭和60年11月 8 日，東京 TEPCO ホール，昭和60年11月11日， 大阪, 中央電気クラブ昭和60年11月 13 日, 技術討論会, 東京, 日本 電球工業会. 招待講師と講演テーマ(1)「赤外反射膜を利用した高 効菜形白熱電球」Dr. I. S. Goldstein（米国 Duro-Test Co.), (2)「人工光に括ける分光分布の最適設計」Dr. P. C. Hughes（同 上).

(b) '86国際シンポジウムの企画

下記招待講師および講演テーマにて進行中.「室内環境におけ る照明と色彩の生理・心理的效果」Dr. R. Küller（スウェーデ ン ルンド工科大学).

\section{$\Leftrightarrow$ 第 4 回日本照明覚審査委員会}

芯募件数 6 件のうや下記 2 件を推蔗すること決定. (1)高速道路 用長大トンネルの照明技術開発, (2)一石他励式インベータの開発 と蛍光灯スタンドへの応用。

(才）照明ハンドブック編集委員会

(a) 学会創立70周年記念事業の一還として出版するハンドブッ
クの編集企画を行なった。

（b） ハンドブックの出版要項を完成，執管委員に原稿執筆を依 頼した.

(c) 新しく出版するハンドブックの概要は次のとおり. (1)書 名：ライティングブック (仮称), (2)判型・ページ数：B 5 判, 690 ページ程度, (3)発行所：オーム社, (4)発行予定：昭和62年 3 月.

( 䜣 国際交流委員会

(a) 委員会規則の作成

(b) 委員会活動方針の決定

(c) 海外の照明関連学会・団体の調査

\subsection{3 功績, 表彰に関する事項}

\section{(1）名誉会員の推戴}

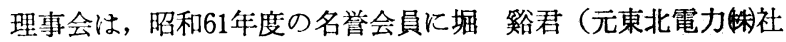
長)を推薦した.

\section{1 .4 総会}

第61回通常総会は, 昭和 60 年 5 月 28 日, 社団法人日本電気協会 会議室に扔いて開催し，昭和59年度事務・事業報告，昭和59年度 収支決算報告，昭和60年度事業計画案，昭和60年度収支予算案， 昭和 $60 ， 61$ 年度役員選任の 5 件が提案され，万場巽議なく承認さ れた. また, 名誉会員, 照明学会賞と日本照明賞の贈呈, 永年勤 続表彰が行なわれた。

\subsection{5 学会運営に関する事項}

学会事業遂行のため理事会12回, 評議員会 4 回, 運営計 画会 議, 部門運営会議を開催し, 必要事項について審議決定した。

\section{1.6 照明学会各支部の活動}

照明学会各支部は照明普及会と連絡を取り，表 11.1.3 のとお り委員会を設计調查研究のほか講演会, 講習会, 見学会などを実 施し普及活動を展開した。

（石塚 直弘・照明学会）

垡 11.1.2 员近の会員のすう勢（各年度末 3 月31日現在）

\begin{tabular}{|c|c|c|c|c|c|c|c|c|c|c|c|}
\hline & 50 & 51 & 52 & 53 & 54 & 55 & 56 & 57 & 58 & 59 & 60 \\
\hline 海道 & & 165 & 308 & 326 & 319 & 319 & 329 & 344 & 332 & 310 & 288 \\
\hline 束 北 & 302 & 325 & 372 & 38 & 345 & 337 & 318 & 371 & 384 & 344 & 344 \\
\hline 東 京 & 2,089 & 2,161 & 2,083 & 2,070 & 2,053 & 2,053 & 2,103 & 2,223 & 2,214 & 2,156 & 2,176 \\
\hline 北 猿 & 248 & 224 & 212 & 210 & 201 & 189 & 176 & 188 & $\begin{array}{l}191 \\
\end{array}$ & 185 & 172 \\
\hline 東 液 & & 329 & 316 & 331 & 344 & 346 & 353 & 403 & 394 & 383 & 410 \\
\hline 閃 西 & & 725 & 710 & 702 & 691 & 723 & 735 & 878 & 886 & 875 & 858 \\
\hline 中 国 & 247 & 242 & 245 & 222 & 205 & 202 & 207 & 207 & 202 & 210 & 226 \\
\hline 四 固 & & 246 & 234 & 209 & 199 & 184 & 188 & 185 & 192 & 190 & 167 \\
\hline 九 州 & 219 & 216 & 220 & 257 & 252 & 266 & 277 & 282 & 292 & 277 & 271 \\
\hline 計 & 4,914 & 4,663 & 4,770 & 4,715 & 4,619 & 4,603 & 4,679 & 5,081 & 5,087 & 4,930 & 4,912 \\
\hline
\end{tabular}

表 11.1.3 各支部に拈ける謂查, 研究, 普及活動

\begin{tabular}{|c|c|c|c|c|c|c|c|c|c|}
\hline 支 & 部 & 别 & 講演会 & 譿習会 & 幽㰴会 & 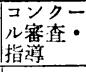 & 調査研究 & 委員会 & 見学会 \\
\hline 北 & 海 & 道 & 1 & 3 & & 1 & & 2 & 3 \\
\hline 東 & & 北 & & 3 & & 16 & & 3 & \\
\hline 東 & & 京 & 3 & 3 & & & & 4 & 2 \\
\hline 北 & & 陸 & 1 & 6 & & & 4 & 1 & 1 \\
\hline 東 & & 海 & 1 & & & & & 2 & 1 \\
\hline 閔 & & 西 & 3 & 1 & & & & 3 & 1 \\
\hline 中 & & 国 & 21 & 37 & & & 1 & & \\
\hline 四 & & 国 & 9 & 1 & & 12 & & 2 & \\
\hline 九 & & 州 & 1 & 3 & & 10 & & & \\
\hline & 計 & & 40 & 57 & 0 & 39 & 5 & 17 & 8 \\
\hline
\end{tabular}




\section{2 照明普及活動}

照明への認識を高め, 照明の質的向上を図るため，住宅照明普 及に関する資料の作成,「新時代に抢ける照明の調查研究」の要約 編集, 照明普及会規約の見直し、コンサルティング教材の作成, 講演会, 軮習会の開催のほか「あかりの日」行事に協力した.

\subsection{1事業委員会}

\section{（1）住宅照明普及資料の作成}

前年度行なった住宅照明の意識調查についての報告書を作成 中. 昭和 61 年度学会誌に揭載し, 維持員には普及資料として配布 する.

（2）「照明の及ぼす農作物への影響」の技術資料の作成 昭和 61 年度継続して実施することとする.

\section{（3）「新時代における照明の調査研究」の要約}

事業委員会内に小委員会を設け，上記報告書の第 2 編「視環境 整備に括汁るグレア制御基準の調查研究」の要約版（A 5 判15ペ 一シ程度）を作成. 昭和 61 年度上期頒布予定.

\section{(4) 照明普及会規約の見直し}

改正に関する委員会を設置し，「照明普及会規則」として 維持 員総会に提出する. 主な改正点は組織全般の見直しをし，役員 会, 運営委員会, 企画推進委員会によって運営することとなっ た.

\section{（5）照明普及賞規約の見直し}

改正に関する委員会を設置し，12月10日より改正実施した. 改 正点は対象をグループまで広げたこと．締め切りを 1 月 31 日に延 長したこと．提出資料を明確化したこと．推蔗書書式を変更した こと.

\section{（6）照明普及賞の贈呈}

昭和59年照明普及賞78件を，昭和60年 5 月 28 日の維持員総会で 表彰.

\section{（7）照明普及賞の選考}

学会誌11，12月号会告で，「昭和60年照明普及賞の推薦につい て」を掲載，その別刷を維持員に送付，昭和 60 年 1 月 1 日以降 12 月31日までに完成した施設と普及貢献者を対象に, 全維持員に推
鹰依頼した．応募総数 360 件．各地区審查後78件（施設74件, 普 及 4 件)、を表彰することに決定した。

\section{（8）コンサルティング教材の作成}

講習会, 講演会の教材として活用できる「店舗照明」のスライ ドを説明書付きおよびテープ付きで有償配布した。

\section{（9）各地区照明講習会，講演会の開催}

学会各支部ならびに各電力会社と共催で照明講演会, 講習会を 開催した. 件数66件，総参加人数は3,334名であった. 表 11.2.1 に講演会, 講習会一覽を示す。

\section{(10) 照明普及連絡研究会}

日時 昭和 60 年 8 月 15,16 日 場所 四国.

\section{(11) 事業連絡会}

日時 昭和 61 年 3 月 10,11 日 場所 束京電力.

\section{(12) あかりの日協替}

「10月21日あかりの日」㸃蒙キャンペーン行事（「あかりの日」 小冊子 $<\mathrm{B} 6$ 判 4 色刷16ページ $>$, 拈よび電球を PR 用特箱に入 れて街頭配布した）を全国10地区（動員 195 名）で10月21日に実 施した．共催団体は社団法人照明学会照明普及会, 社団法人日本 電球工業会, 社団法人日本電気協会, 社団法人日本照明器具工業 全.

\section{(13) そ の 他}

維持員 12 社より 24 件のカタログを提供いただき，9地区へ 2 部 ずつ送付した。

\section{2 .2 資 料委員会}

\section{(1) あたらしい照明の発行}

あたらしい照明98号「昭和59年照明普及賞」号（昭和60年 5 月 発行） 4, 000 部, 99号「新照明施設」号（昭和 60 年 10 月発行） 3,700部を維持員へ有償配布。

\section{(2) 照明教室の発行}

照明教室 No. 61 「光放射の店前 I」(昭和60年10月）4, 000 部 発行, No. 62 「光放射の応用 II」(昭和60年 2 月) 4,009 部発行し 有償配布した。

（石塚们弘・照明学全）

表 11.2.1 各地区照明講習会一覧（昭和60年度）

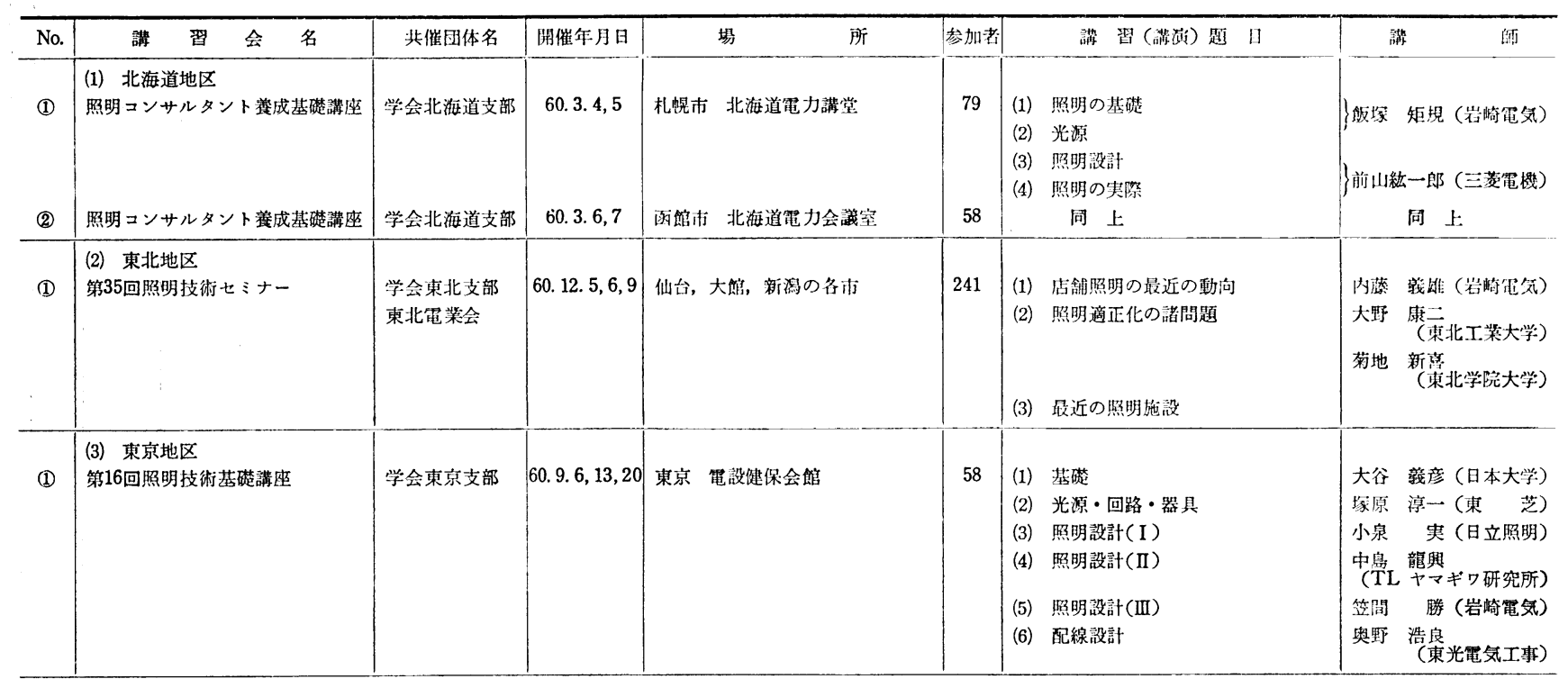




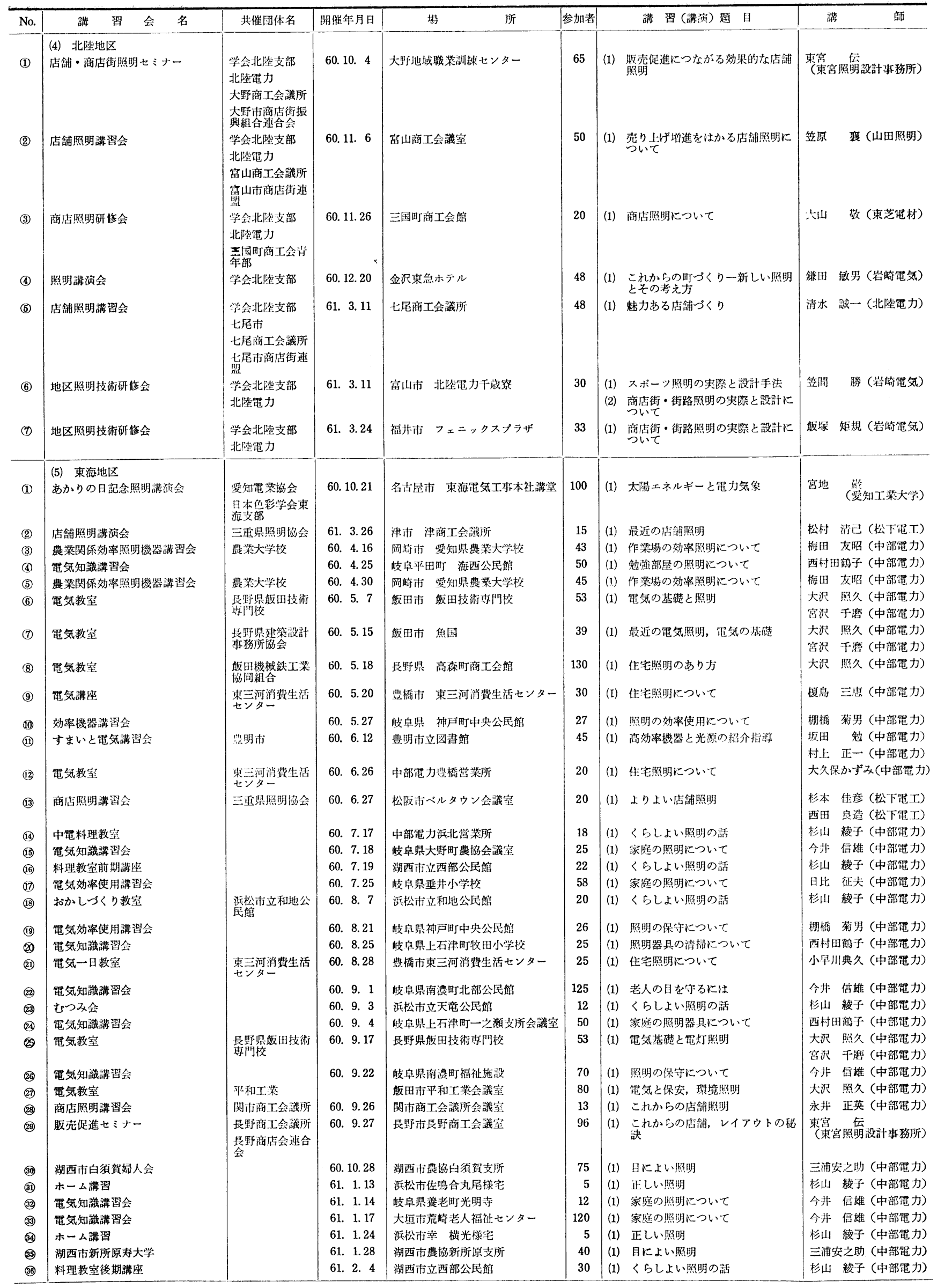




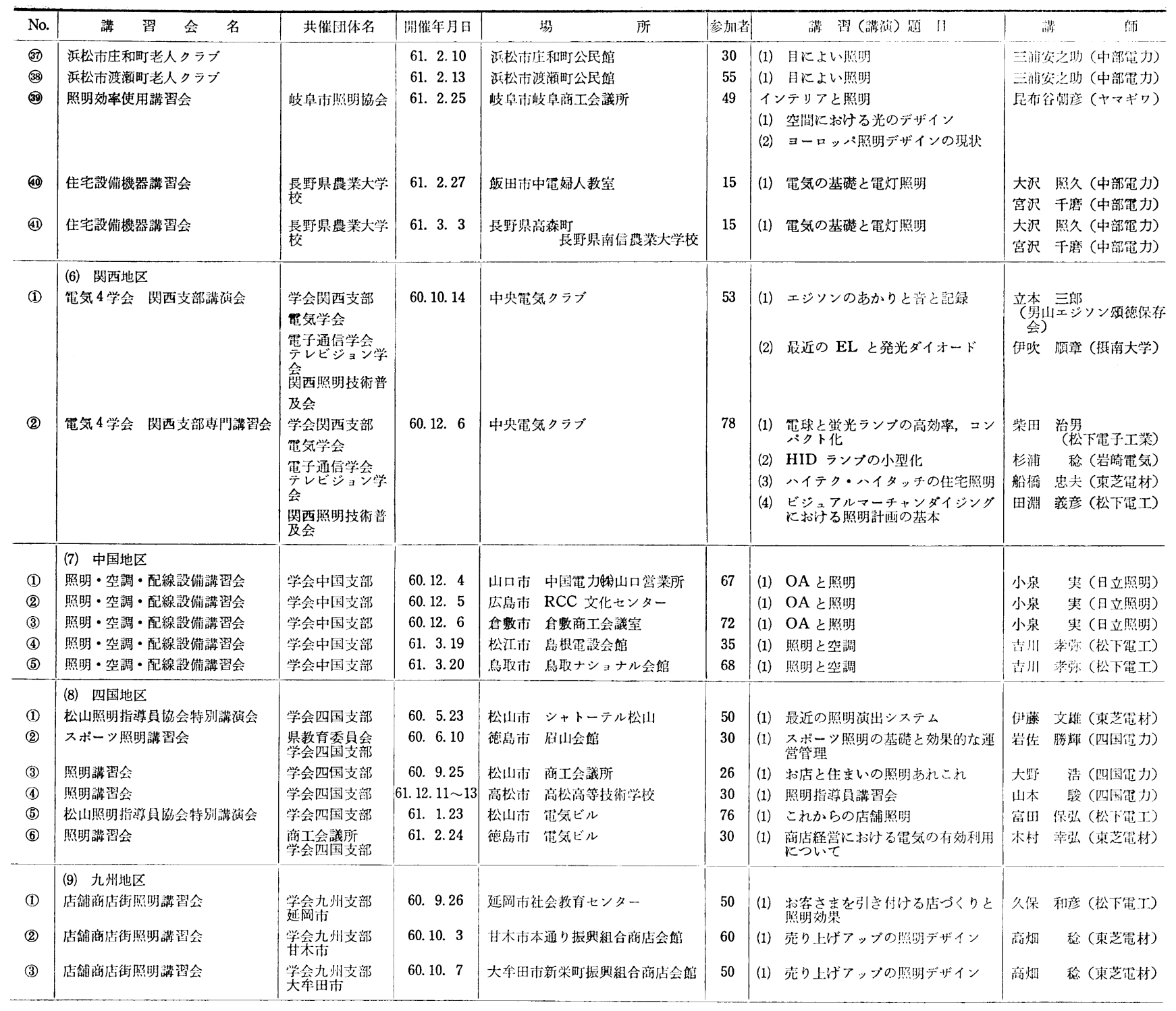

\section{3 日本照明委員会の活動}

\subsection{1 運営委員会の活動}

(1) 事業運営委員会 (松浦 邦男委員長, 3 回開催)

本委員会は，昭和59年度に設置されて以来，財政基盤の充実の ために維持会員の增加活動を進めてきた。昭和59年度は12社17口 の申し込みがあり, 昭和60年度はさらに 2 社 2 口の新会員を得 た、また，JCIE の国際交流基金の利子による国際交流費の使途 について規定案を作成した、理事会はこれを承認し国際活動の一 段の活発化が期待される.

（2）技術運営委員会（成定 康平委員長，5回開催）

本委員会は, 各部会担当の委員から CIE の各部会の活動報告 を定常的に受けるとともに，その概亚を日本照明委員会誌を通じ て会員に報告した．CIEの各技術部会会議，技術委員会会議に対 する会員の参加は活発で，わが国の研究活動に対する各国の評価 が高まった。昭和59年度に行なった「日本照明委員会規則」の一 部改訂に呼応して,「日本照明委員会国内委員会等運営手続規約」 の改訂を行ない, 円滑な技術活動ができるように基盤を整備し
た. 1987年開催の CIE ベニス大会に问けての発表論文の募集を 開始した。

\subsection{2 国内委員会の活動}

（1）第 1 部会「視敩と色」国内委員会（池田光男要只長，2 回 開催)

積極的な国際活動を行なうために，TC 委員として，TC 1-11 「色再現用照明」に大田氏を，TC 1-14「視覚への照明効果」に 武内氏を推薦し承認された。また，1985年 6 月にパリで開催され た部会会議には，各 TCへの参加分担を検討し情報収集と意見の 反咉を行なった、そのほか第 1 部会の投票関わる事項を検討 しわが国の意見が反映されるよう努めた。

(a) TC 1-08「色差評価」国内技術委員会（川上，元郎主查， 2 回開催)

6 月14日パリーで開催された CIE TC 1-08 委員会に, 川上主查 と小松原委員が出席し, 日本の研究実情を説明するとともに情報 交換を行なった：また国内技術委員会では上記の報告や関連する 
AIC の色美研究状況, 各委員の研究進捗等の報告が行なわれた。

(b) TC 1-12「相対演色」国内技術委員会(森 礼於主查, 5 回 開催.ただし 4 回は照明学会演色評価方法研究調查委員会 に併摧）

$\mathrm{CIE}$ 評価力法第 3 版案について, パリ会議向けの日本提案をを とめて，それを提案した．同会議では，色空問，色順応補正式は 日本提案どおりになったが，評価数の尺度化の新方式は採用され なかった．その後，国際的方法に用いられるように日本人の肌色 データを補強すること，および尺度化方式の再検討を進めてい る.

（2）第 2 部会「光と放射の物理測定」国内委員会（西 師狡委 員長, 2 回開催)

$\mathrm{CIE}$ 第 2 部会のパリ会議についての対応を協議した。 TC 2-05 「分布温度の定義と測定」の第 1 ドラフトの検討, TC 2-07「光 沢の測定」の最終ドラフトの審議と賛成投票を行なった. パリ会 議では TC 2-08 に関連する蛍光色の測定について発表した。 た，設置の決まった TC 2-21「せん光の放射測定」の委員長候補 として近藤英樹氏を推蔗し承認された。

新に七つの TCの発足に伴い，その国内担当委員を決めた.

（3）第 3 部会「屋内環境亡照明設計」国内委員会（松浦 邦男 委員長, 2 回開催)

昭和60年 7 月10日第 2 回委員会が開催され，各 TC 活動の情報 を交換した．TC 3-01，3-03の委員に金谷末子氏が正式に委嘱さ れた. 10月23日には第 3 回委員会が開かれ，9月11日ローザンヌ （スイス）で開催された第 3 部会会議の概要が，出席した松浦委 員長および沖委員より紹介され，新しく TC 3-11「昼光照明計算 方法」の設置, 副部会長に Kendrick 氏が新しく任命されたこと などが報告された

(a) TC 3-07「昼光測定資料の収集」国内技術委員会（中村

洋主查, 2 回開催)

昭和60年 7 月 10 日 Kendrick TC 委員長からの TC ローザンヌ 会議（9月13，14日開催）の審議事項案について検討した. 10月 23日には中村主査の代理として上記 TCに出席した沖委員が，粤 議状況とくに日本からの標準測定装置の提案について報告した.

(b) TC 3-09「標準としての平均天空」特別技術委員会（松浦 邦男委員長, 2 回開催)

昭和60年 7 月 10 日松浦委員長より，TC ローザンヌ会議（9月 13，14日）の審議資料「平均天空の構成方法」について，委員か ら意見を集めた。10月23日上記会議に出席した委員長より審議状 況について報告があった

（4）第 4 部会「交通用の照明と信号」国内委員会（吉村 義典 委員長, 1 回開催)

昭和60年10月15日に委員会を開催し， CIE 第 4 部会ローザンヌ 会議, および関連 TC委員会の活動状況について情報交換し, 積 極的に JCIE 会誌に報告することを申し合わせた。また新しい TC「鉄道信号」の担当を稲垣委員に, TC 4-0.9夜間運転の視覚 作業」の担当を吉村委員長から河合委員に変更した.

成定委員が TC 4-08「トンネル照明」のローザンヌ会議に, 本 田委員が TC 4-10「自動車灯火類」のブラッセル会議にそれぞれ 出席した。

（5）第 5 部会「屋外およびその他の照明応用」国内委員会（斎 藤 辰弥委員長, 4 回開催)

主として次の事項を行なった. (1)関連 TCの活動状況および意
見交換，(2)ドラフト等の賛否投票に対する検討と発信，(3)関連す る CIE 出版物の日本語訳の作成.

（6）第 6 部会「光生物学と光化学」国内委員会 (河本康太郎委 員長, 2 回開催)

昭和60年 5 月19日に第 3 回委員会を開催し, CIE 第 6 部会パリ 会議の議題につき対応方を協議した. その結果を委員長の代理と して出席する森会長に付託した．また第 6 部会に関連する製品の 調查を行なった。

昭和60年 11 月 9 日第 4 回委員会には, ダストとして米国 CIE 第 6 部会委員 Hughes 氏と Goldstein 氏の出席を得て, 第 3 回 CIE 第 6 部会会議の状況とその対応策について協議した.なお Hughes 氏らとは，米国に拈ける CIE 対応組織の 現状等につい て情報交換した。

(7) 第 7 部会「照明の一般的問題」国内委員会（成定康平委員 長)

特に定例的委員会会議は開催しなかった. 光源技術委員会 (TC 7-02）では，CIE の技術委員会の作業計画港づき, 報告書の作 成作業の一部を分担した.

\subsubsection{CIE中間総会}

昭和60年 9 月, CIE のローザンヌ中間総会に森会長と松浦副会 長がわが国の代表として，成定副会長が CIE の評議会委員として 出席した．総会は Wyszecki 会長の急逝を悼んだのち, CIEの次 期大会の準備状態について，ベニスで1987年 6 月 17 日から 6 月 25 日の間開催されること，CIE の新技術組織が順調に運用されつつ あること，各国際機関との連携が改善されつつあること，出版業 務が合理化されつつあること，CIEの本部を数年以内に，現在の カナダのオタワからオーストリアのウィーンに常設的に移転する こと、ニュージランドが新に加盟したことなどの報告があった. 後任の臨時会長に, 出版担当の副会長であった香港の Marsden 氏が選任された。

\subsubsection{CIE 部会長および CIE 技術委員会委員長等としての 本会会員の活動}

（1）第 7 部会「照明の一般的問題」(成定 康平部会長)

ローザンヌの部会会議および一部の技術委員会会議に，成定副 会長と井上猛氏が出席した。TC 7-01「照明用語」では，IEC と 共同で作成中の照明用語集第 4 版を，1986年末完成を目途に最終 作業中である. TC 7-02「光源」では, 光源, 放射源, 電子点灯 装置の分野について現状の調査報告書を準備中である.

（2）第 1 部会「視覚と色」(池田 光男副部会長)

第 1 部会パリ会議に TC 1-01から TC 1-05の活動報告を行なっ た、抒おむね順調に進展している。

\section{（3） TC 1-02「比視感度関数」(池田 光男委員長)}

TCレポート「Brightness Luminous Efficiency Functions for Monochromatic Point Sources, $2^{\circ}$ and $10^{\circ}$ fields $」$ 第一 案を作成しパリ一会議で報告した.つついて第 2 案を作成して各 $\mathrm{TC}$ ×ンバーへ送付，メンバーの意見を加味して最終案を作成 し，Bodmann 部会長に提出した，第 1 部会の投票に回される予 定.

(4) TC 1-07「観測者メタメリズム」(大田 登委員長)

観測者メタメリズムの評価方法について検討してきたが，納谷 嘉信氏の研究を基礎とした第一次報告書を作成した。これをパリ 会議で討議し修正中である１987年イタリア大会を経て技術報告 して出版する計画である.

J. Illum. Engng. Inst. Jpn. Vol. 70 No. 71986 - 95 - 
(5) TC 2-21「せん光の分光放射測定」(近藤 英樹委員長)

本 TC は1985年 9 月 7 日に開催された CIE ローザンヌ評議会 で設立が承認され，11月15日付でメンバーリストとべニス大会ま での活動計画表を，当時の Grum 部会長に送付した。昭和61年 1 月 31 日付で, 5 月 1 日期限の Preliminary draftを各メンバー に送付した。

(6) TC 3-09「標準としての平均天空」(松浦 邦男委員長)

中間天空, Average 天架, Mean 天空の定義, すでに CIE 標 準となっている晴天空・墨天空, および中間天空より平均天空を 構成する方法, 三つの基本天空の天顶輝度值の提案等について口 ーザンヌ会議で討議し，大筋の考方方として委員長案が承認さ れ，第一次草案作成に着手した.

（7）TC 6-06「照明用光源の紫外放射」(河本康太郎委員長）

1985年 6 月の第 6 部会会議において, 分光分布データの収集状 況などの中間報告を行なった. 西独およびハンガリーのデータ要 望が出され，両国からの委員の委嘱を行ないデータ収集中であ る.

\section{3. 5 CIE 本部会議・CIE 部会等への本会会員の出席状況}

（1）昭和60年 9 月 7 日にローザンヌで開催された CIE 本部総 会に，森会長，松浦・成定両会長が出席した。 会長会議, 6 日の評議会会議に成定副会長が出席した.

（2）昭和60年 6 月 $14 ， 15$ 日にパリで開催された CIE 第 1 部会 会議扣よび関連 TC 会議に, 池田副部会長, 一条氏, 大田 TC 委 員長, 川上委員, 栗岡 TC 委員, 小松原国内委員, 佐川 TC 委 員, 納谷 TC 委員, 橋本氏, 森会長が出席した。

（3）昭和60年 6 月 $12 ， 13$ 日にパリで開催された CIE 第 2 部会 会議扣よび関連 TC 会議に, 栗岡 TC委員, 馬場 TC委員, 森会 長が出席した。

(4) 昭和 60 年 9 月 $8 ， 11 ， 12 ， 13$ 日にローザンヌで開催された 第 3 部会会議および関連 TC 委員会に㐨いて, 松浦委員長が TC 3-09を主催し沖国内委員, 永田 TC 委員が出席した. 第 3 部会会 議と TC 3-07k松浦委員長と沖国内委員が出席した。

（5）昭和60年 9 月 $13 ， 14$ 日の第 4 部会会議に成定副会長と井上
氏が出席した。

(6) 昭和60年 6 月 $10 ， 11$ 日にパリで開催された第 6 部会会議に 森会長が出席した.

(7) 昭和60年 9 月 $11 ， 12$ 日にローザンヌで成定部会長が第 7 部 会会議を主催した。

11.3.6 出 版 関 係

（1）本会会誌は「日本照明委員会ニュース」から「日本照明委 員会誌」に改名, 同時に編集委員会（委員長：栗田正一）を正式 に組織し 3 回開催した. 会誌発行数は約 450 部で, 本年度は No. 67〜No. 70 の発行, 配布を行なった.

(2) CIE ニューズレター No. 30〜No. 33 を配布した.

(3) 下記の CIE Publ. を頒布した.

No. 65 Electrically calibrated thermal detectors of optical radiation

No. 66 Road surfaces and lighting

(4) 下記 CIE 出版物の日本語版を出版し, 関係方面に PR し た.

No. 60 Vision and the VDU Work Station

(5) 第 6 回日本照明委員会大会予稿を出版した。

\subsection{7 第 6 回日本照明委虽会大会の開催}

昭和 61 年 2 月 7 日(金), 日本電気協会会議室において開催し, 39件の講演を中心に大盛会だった．参加者数85名.

\subsection{8 諸会合および会勢}

炤和 60 年度には通常総会 1 回 ( 5 月 28 日), 評議員会 2 回, 理 事会 7 回を開催. 昭和 61 年 3 月 31 日現在の会勢を前年度末と比較 すると表 11.3.1 のとおりである. （高橋 貞雄・東芝電材）

表 11.3.1 会 勢

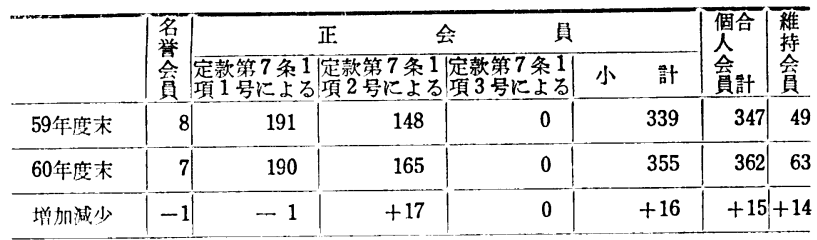

\section{4 国際照明委員会活動}

\subsection{1 総 括}

1985年の活動の主なるのは, (1)この年が 4 年ごとの CIE 大会の 中間年に当たるために，9月に中間総会が開催され，アムステル ダム大会以降 2 年間の活動がチェックされ調整されたこと，およ び今後 2 年間の活動方針が確認されたこと，(2)CIE の各部会・技 術委員会は，それぞれに発足後第 2 回あるいはそれ以上の会議を 開催し，技術活動が本格的に始動していること，(3)Wyszecki 会 長, Grum 第 2 技術部会長が急逝され，本部役員に若干の变更が 行なわれたことの 3 点である.

\subsection{2 本部関係の会議}

1985年 9 月にスイス・ローザンヌで, 下記の本部関係の会議が 開催された.

(1) 技術部会長会議（9月 4 日）

(2) 本部理事会（9月5日）

(3) 評議会 (9月 6 日)

(4) 中間総会 (9月 7 日)
左記(1) (3)の会議で審議された事項は, 最終的に(4)の中間総会 で報告され承認された。これらの会議のらち，(1)，(3)にはわが国 から成定副会長が，(4)に心森会長と成定副会長がそれぞれ出席し た.

\subsection{3 本部役員の変更}

前述のように，1985年6月に CIE 会長であった Wyszecki 氏 が病気で急逝され，同年12月には第 2 技術部会長の Grum 氏が 自動車事故のために亡くなられた.このため $\mathrm{CIE}$ 本部役員に一 部変更・補充の必要が生じ, 次のように決定された。

すなわち，会長には Marsden 氏（前出版担当副会長）が，出 版担当副全長には Aldworth 氏（前第 5 部会長）が，第 5 部会長 には van Bommel 氏（前 TC 5-04 おおよび TC 4-08 委員長）が それぞれ指名され就任された。第2 技術部会長の後任者は，1985 年末時点で末定である.

\subsubsection{CIE 本部の所在地の変更}

現在 CIE の本部は, カナダ・オタワの国立研究所 (National 
Research Council) 内に仮設置されている.かねてから CIE は 永久的な本部を設置する計画を持って拈り，その所在地につい て，この数年間関係者の間で検討してきた. イギリス，西ドィ ッ, スイスその他いくつかの候補地に対して, 永久的本部を設置 した場合の運営費その他について比較検討を行なった結果, 9 月 の中間総会でオーストリアのウィーンとすることを決定した.

この永久的本部の新設の時期は，1987年の CIE ベニス大会以 降になる予定である（これに合わせて，永久的本部に常駐する CIE 専属の事務局長が公募された).

\subsubsection{CIE の財務状況}

現在 CIE の財務状況はかなりの黑字基調である.このことか ら，さきの中間総会でアメリカ等から CIE の各国分担金の減額 が提案された. しかし一度分担金を引き下げると必要なときに再 び引き上げるのが困難であること，扣よび前述の CIE 永久的本 部の新設に伴う費用の増加を見込まなければならないことなどの 理由で，分担金は現状のままにして抢くことになった.

\subsubsection{CIE の新加盟国}

9 月の中間総会で, ニュージーランドの加盟が承認された. 中 国の加盟については，現在中国が日本照明委員会支援のもとに国 内の三つの照明学会の間で, CIE 国内委員会の結成について検討 中である.このほかケニアとインドが加盟について検討してい る.

\subsection{7 技 術 活 動}

各部会（傘下の技術委員会を含む）の技術活動は, テクニカル レポートの作成を目指して本格的に動いている. 9 月の技術部会 長会議で, ケンブリッジ会議（1984年 4 月）以降の七つの技術部 会の活動状況の報告と調整が行なわれた.

調整・決定された事項の中で, 主なものは次のようであった。

(1) CIE の活動について関係者の情報交流を活発にするため に, 各部会は部会会議議事録のほか, 部会活動報告を年 2 回以上 発行することになった.

一方, CIE と各国内委員会との情報交流の欠如は各国内委員会 の部会委員などの消極性も原因の一つであるために, 各部会は活 動の活発でない部会委員, TC 委員長・委員に対して態免を含む 適切な処膡をとることになった。

（2）「CIE 用語」は現在第 4 版を作成中で, 完成は1987年以降 の予定である. しかし第 4 版の作成が遅れ気味であること, およ び（年々変化していく）用語といら性格上, 第 4 版完成後, 直ち に第 5 版の「CIE 用語」作成の基礎を固めることが必要であるこ とから，これを専門に扱らグループを第 7 部会内に設けることに なった.このグループには各部会から 1 人ずつ代表が参加して編 成される.

（過去 2 年間の各部会・委員会の活動の具体内容については， 昭和 61 年 2 月の日本照明委員会大会の講演予稿集に紹介されたの で本稿では省略する)

\subsubsection{CIE 出版 物}

1985年中に CIE から出版された主な出版物は，次のとおりで あった.

OCIE Publication No. 65: Electrically Cariblated Thermal Detectors of Optical Radiation (Absolute Radiometers) OCIE Publication No. 66: Road Surfaces and Lighting

(PIARC との共同報告書)

OCIE Code of Procedure for CIE Sessions OCIE ジャーナル Vol. 4 No. 1 および Vol. 4 No. 2

このように, CIE Publication の出版が 2 種類と例年になく少 なかったのは，前年に多く（6 種類）出版されたためである.

また，CIE ジャーナルの発行について次のような拔本的な方針 が打ち出された。

（1）従来の同ジャーナルの無償配布制を中止し，申し込みによ る有償購読制に切り替兄る. 具体的には, 各国内委員会に対して $\mathrm{CIE}$ 会費分担ユニット 5 ニニットごとに 1 冊を無償配布し，その 他のものは 1 巻（年 2 冊）につき各国照明委員会は 16 ドル，その 他には32ドルで領布する.

（2）同ジャーナルの購読者管理，発送・広告などの発行業務 を, CIE 独自で行ならことは困難なので，これについて職業的能 力を有するいずれかの国の照明の学会に委託する（このため, 現 在イギリスの CIBSE 等と協議中であるが, 詳細は未定).

\subsection{9 第21回 CIE 大会の計画}

9 月の中間総会で, 上記大会の基本計画が報告, 承認された.

それによると，

○期間 1987年 6 月 17 25日

○場所 イタリア・ベニス San Giorgio Maggiore 島

で行ならことにして準備が進められており, 期間中の概略スケジ ュールは次のようである.

6/17 AM : 総会, PM : 開会式

6/18〜20 終日: 講演発表, ポスター展示ほか

$6 / 21$ 休日

6/22〜24 終日：部会会議（ 3 平行セッション）

6/25 AM：部会会議, PM：閉会式

6 月22２5日の部会会議は, 三つの会場でそれぞれ平行して行 なわれる、これまでの大会と異なる点は, 会議室の関係で部会傘 下の各技術委員会（約80個）の会議が会場予定地では開催不可能 であることで, 開催の必要があると考劣る各技術委員会は, 別途 計画・設定する必要があることである.

なお，この大会への研究発表については，すでに照明学会の会 告などで周知のとおり, 現在, 予稿（概要）が募集されており, 日本照明委員会の事務局へ5月20日までに送付されてきたものを 審査のら光，6月20日までに CIE 本部へ送付することになって いる.

(成定 康平・松下電器産業) 